\title{
Digitalisasi Industri Perfilman Korea Selatan Melalui Netflix Sebagai Alternatif Pasar Ekspor Film
}

\author{
Faradina Tshania Laily ${ }^{1}$, Adiasri Putri Purbantina ${ }^{2}$ \\ 1Universitas Pembangunan Nasional "Veteran" Jawa Timur \\ 2Universitas Pembangunan Nasional "Veteran" Jawa Timur \\ E-mail: faradina.tshanialaily@gmail.com
}

\begin{abstract}
The global pandemic COVID-19 threatens both global health and the global economy, including the film industry. Throughout 2020, the international movie industry experienced a significant market decline due to various social distancing measurements. South Korea, enjoying its cultural export boom (e.g., Korean drama, Korean film), is not an exception. South Korean film industry experienced a sharp decline in their sales and revenue. The challenges from COVID-19 to the global film industry led to a market transformation, especially regarding global film distributions. Netflix, an online streaming platform, becomes one of the key players within this phenomenon. This paper employs a qualitative method to analyze the South Korean film industry's export strategy transformation through Netflix. The paper found that South Korean film industries experienced a 13,3 \% increase in exports in 2020, with 975 movies. There is increasing consumer interest in South Korean culture, actors, and stories as more Korean movies are accessible through Netflix.
\end{abstract}

Keywords: Film Industry, South Korea, COVID-19 Pandemic, Transformative Marketing, Netflix

\section{Pendahuluan}

Industri perfilman merupakan salah satu sektor industri budaya yang memiliki pasar yang luas secara global. Meskipun persaingan pasar film global didominasi oleh film produksi Amerika, negara-negara di luar benua Amerika juga tetap memiliki sektor industri perfilman yang berjalan secara dinamis baik di pasar domestik maupun pasar film internasional. Tidak dapat dipungkiri bahwa Hollywood merupakan sebuah bukti industri perfilman populer di kancah internasional akibat sejarah produksi dan pasar film yang luas. Oleh sebab itu, Hollywood menjadi kiblat industri perfilman global dari segi kualitas produksi hingga promosi film-filmnya, baik dalam pasar domestik maupun internasional yang sangat masif dan stabil (Ibbi, 2013).

Terlepas dari kepopuleran pasar film global oleh Hollywood, negara-negara lain di dunia juga memiliki sejarah industri perfilman yang sangat beragam. Keragaman ini dapat dilihat dari segi kualitas film, perkembangan bioskop, kebijakan pemerintah terkait pasar film, budaya menonton film dalam masyarakat, dan performa pasar industri perfilman. Menurut Richeri (2016), bioskop memiliki peran vital bagi prosentase pendapatan film. Pendapatan tersebut bersumber dari penjualan tiket film, terutama pada minggu pertama dan kedua perilisan film tersebut. Jumlah total penjualan tiket film melalui bioskop menjadi tolok ukur utama nilai pasar film untuk kemudian dirilis dalam bentuk lain, seperti dalam bentuk digital video disc (DVD), video on demand (VOD), dan penayangan di televisi berbayar. Berdasarkan data dari Comscore, pendapatan Box Office secara global pada tahun 2019 memecahkan rekor dari tahun sebelumnya yang mencapai 42,5 miliar dollar AS; naik sebesar 2\% dari tahun 2018 dengan pendapatan Box Office sebesar 41,1 miliar dolar AS. Dengan sumber data yang sama, sejak tahun 2012 industri perfilman global selalu mengalami kenaikan yang cukup signifikan dan stabil, baik dari jumlah produksi film hingga total penjualan tiket dan pendapatan (Ripley N. , 2020). 


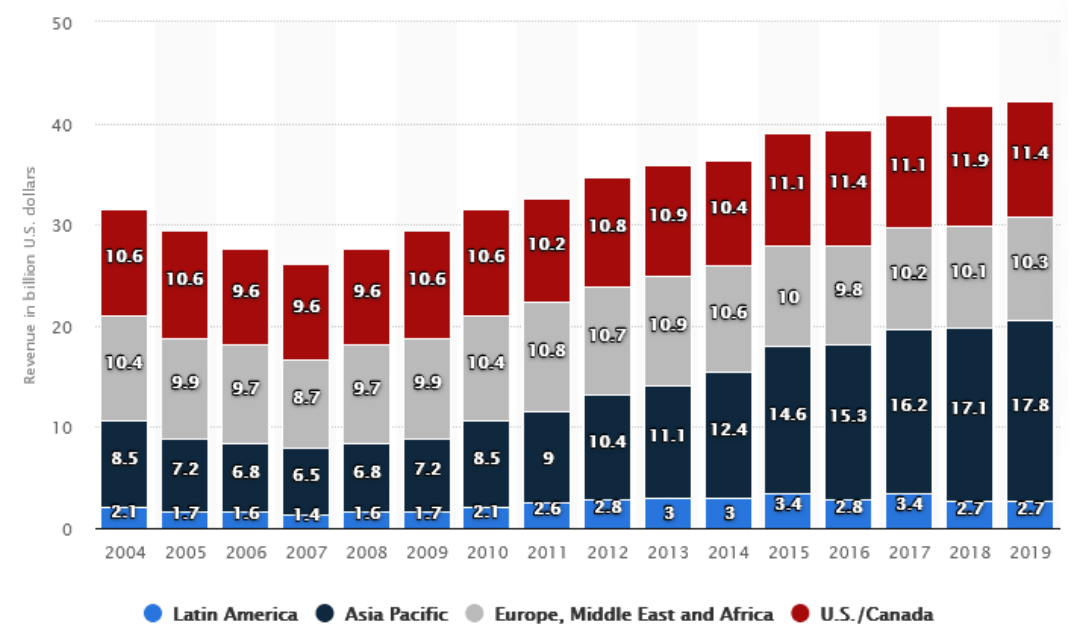

Grafik 1. Pendapatan Box Office global per regional tahun $2004-2019$

(dalam miliar dollar AS)

Sumber: (Stoll, 2021)

Namun, pandemi global COVID-19 berdampak besar bagi industri film global. Hal tersebut mengakibatkan sebagian besar pemerintah negara-negara di dunia mengeluarkan berbagai macam kebijakan pemerintah yang sangat terpusat pada keamanan dan kesehatan masyarakat negaranya dengan memberlakukan pembatasan sosial, penutupan wilayah (lockdown), danpembatasan aktivitas masyarakat. Terlebih lagi, dengan berlakunya kebijakan lockdown oleh sejumlah negara maka dapat dikatakan kebijakan ini sebagai pemberhentian sebagian besar pemasaran film. Hal tersebut dibuktikan dengan turunnya pendapatan Box Office global pada tahun 2020 yang mencapai 70\% dari tahun 2019 yaitu hanya sebesar 12,2 miliar dollar AS (Tabel 1).

Tabel 1. Data Box Office Global tahun 2012 - 2020

\begin{tabular}{cc}
\hline Tahun & $\begin{array}{c}\text { Pendapatan Box Office } \\
\text { Global }\end{array}$ \\
\hline $\mathbf{2 0 2 0}$ & 12.200 .000 .000 \\
$\mathbf{2 0 1 9}$ & 42.500 .000 .000 \\
$\mathbf{2 0 1 8}$ & 41.800 .000 .000 \\
$\mathbf{2 0 1 7}$ & 40.900 .000 .000 \\
$\mathbf{2 0 1 6}$ & 39.300 .000 .000 \\
$\mathbf{2 0 1 5}$ & 39.100 .000 .000 \\
$\mathbf{2 0 1 4}$ & 36.400 .000 .000 \\
$\mathbf{2 0 1 3}$ & 35.900 .000 .000 \\
$\mathbf{2 0 1 2}$ & 34.700 .000 .000 \\
\hline \multicolumn{2}{c}{ Sumber: (Ripley N.,2021) }
\end{tabular}

Di tengah penurunan pendapatan industri perfilman terutama pada sektor distribusi melalui bioskop, layanan streaming mengalami peningkatan kepopuleran yang kemudian menjadi solusi alternatif kegiatan distribusi film. Dalam jurnal yang ditulis oleh Mikos (2020) tentang produksi dan konsumsi film pada masa pandemi COVID-19 di Jerman menjelaskan bahwa terdapat dua alasan turunnya minat penonton bioskop (cinemagoers) pada masa pandemi COVID-19, yaitu: (1) sedikitnya jumlah film yang menarik disebabkan oleh penundaan hingga berhentinya kegiatan produksi film; dan (2) kebijakan pemerintah terkait keamanan dan kesehatan yang menutup sementara bioskop sehingga mengurangi minat untuk pergi ke bioskop. Alih-alih menonton di bioskop, peminat film kemudian beralih menggunakan layanan film streaming. 
Berdasarkan survei di Jerman, sebesar 27\% responden menyatakan bahwa mereka mengakses streaming platform lebih sering dari sebelum masa pandemi COVID19. Kedua alasan turunnya minat cinemagoers pada masa pandemi COVID-19 tersebut di atas menjadi masalah utama bagi pasar distribusi perfilman global karena pada dasarnya produksi film global juga mengalami penurunan produksi akibat sulitnya akses produksi dan kebijakan pemerintah yang mempersulit akses cinemagoers pada bioskop (Mikos, 2020).

Seiring dengan kenaikan data penjualan tiket bioskop global pada tahun 2019,, industry perfilman Korea Selatan juga mengalami peningkatan di pasar film global. Hal tersebut ditandai dengan kesuksesan film Parasite (기생충; gisaengchung) yang dirilis pada tahun 2019 dan mendapatkan banyak penghargaan dari masyarakat global, baik dari segi sinematik maupun dari segi penjualan dan pendapatan (KOFIC, 2019). Film Parasite berhasil memenangkan empat kategori Oscar 2020, yaitu best picture; best director; best original screenplay; dan best international feature film. Keberhasilan ini memberikan citra positif pada produksi film Korea Selatan di mata konsumen film internasional sehingga secara tidak langsung memberikan peluang perluasan pasar budaya Korea Selatan di kancah global melalui produk film di samping produk $k$-pop dan $k$-drama (Mojo, 2020).

Namun di tengah sorotan perhatian konsumen film internasional pada film produksi Korea Selatan, pandemi COVID-19 menjadi ancaman kegiatan produksi dan pemasaran film Korea Selatan ke pasar global. Industri perfilman Korea Selatan mengalami penurunan pendapatan yang cukup signifikan akibat penerapan kebijakan pemerintah terkait pembatasan kontak sosial sehingga memberikan dampak pada penjualan tiket bioskop.

Pemerintah Korea Selatan pada dasarnya tidak menetapkan kebijakan lockdown penuh pada negaranya, tetapi lebih menekankan kebijakan pembatasan kontak sosial yang sangat ketat sebagai bentuk preventif agar tidak terjadi penyebaran virus COVID-19 yang lebih luas (Klingebiel, 2020). Akibatnya, pembatasan sosial tersebut mengubah budaya menonton film masyarakat Korea Selatan menjadi menonton film via layanan streaming. Hal ini seiring dengan kenaikan pasar Netflix pada industri perfilman Korea Selatan. Direktur Eksekutif Netflix Reed Hastings dalam Kim, 2020 mengungkapkan bahwa salah satu alasan masuknya Netflix dalam pasar layanan streaming Korea Selatan adalah, karena Korea Selatan merupakan negara yang memiliki teknologi komunikasi dan broadband yang kuat serta standar konsumen yang tinggi. Hal ini membuat Korea Selatan menjadi pasar layanan berbasis internet yang sangat masif dan merupakan salah satu pasar yang sangat strategis dan menguntungkan bagi Netflix untuk pemasaran konten Netflix dan kegiatan produksi Netflix Original.

Dengan kondisi industri perfilman global yang menunjukkan penurunan akibat ditutupnya bioskop sebagai pasar utama industri perfilman, serta dengan munculnya kepopuleran pengguna layanan streaming, peneliti menganalisis kasus pasar ekspor industri perfilman Korea Selatan yang menggunakan cara distribusi film secara digital melalui layanan streaming sebagai respon untuk menghadapi kesulitan pemasaran secara tradisional melalui bioskop di masa pandemi COVID-19.

Sektor ekspor budaya Korea Selatan yang lebih dikenal dengan 'hallyu' memiliki pasar yang cukup besar secara global sehingga muncul fenomena 'hallyu wave' dalam sektor budaya yang terbagi menjadi produk drama, film, animasi, variety shows, musik, buku, game, fashion, kecantikan, webtoon, dan makanan. Inilah yang menjadi salah satu alasan peneliti menggunakan Korea Selatan sebagai studi kasus. Terutama pada sektor industri perfilman. Selain itu, citra industri perfilman Korea Selatan juga meningkat positif pasca kesuksesan film Parasite yang semakin mempopulerkan film-film produksi 
Korea Selatan lainnya di kalangan konsumen film dunia. Hal ini kemudian membuat Korea Selatan menjadi lima besar negara dengan pendapatan penjualan film di bawah Amerika Serikat, Cina, Jepang, dan Inggris (Lulkowska, 2020). Hal tersebut mendorong peneliti untuk mengetahui lebih lanjut terkait bagaimana transformasi industri perfilman Korea Selatan dengan menggunakan layanan streaming Netflix sebagai alternatif pemasaran film di pasar global pasca pandemi COVID-19. Dalam penelitian ini peneliti akan menjelaskan kondisi pasar ekspor film Korea Selatan sebelum terjadinya pandemi COVID19 yang kemudian mengalami perubahan strategi pemasaran menggunakan layanan streaming Netflix.

\section{METODOLOGI}

Berdasarkan rumusan masalah yang diusung oleh peneliti pada penelitian ini, maka penelitian ini dipaparkan sebagai penelitian kualitatif dengan menggunakan studi kasus. Penelitian kualitatif dengan menggunakan studi kasus dapat diartikan sebagai metode penelitian yang digunakan untuk menjelaskan suatu fenomena atau peristiwa tertentu dengan pemaparan data terkait (Alexander, 2005) Peneliti menggunakan sumber data sekunder dalam bentuk data kepustakaan dengan variasi sumber dari penelitian terdahulu dengan topik yang relevan, laporan resmi dari lembaga atau perusahaan terkait serta berita-berita yang dapat dipertanggungjawabkan kredibilitasnya.

Untuk memaparkan analisis data, peneliti berfokus pada analisis proses terjadinya transformasi strategi pemasaran ekspor industri perfilman Korea Selatan melalui layanan streaming Netflix. Peneliti menggunakan sumber data sekunder dari laporan resmi pemerintah Korea Selatan tentang industri perfilman yang dimuat dalam Korean Film Council (KOFIC) dan Korean Foundation for International Culture Exchange (KOFICE) untuk menganalisis kondisi pasar ekspor produk film dengan media distribusi digital. Kemudian, untuk melihat pertumbuhan minat pengguna layanan streaming pada konten film Korea, peneliti menggunakan sumber data dari situs web resmi layanan streaming Netflix dan sumber berita. Untuk melihat bentuk kerja sama atau hubungan antara distributor film domestik Korea Selatan dengan distributor film internasional melalui Netflix, peneliti menggunakan sumber data dari laporan perusahaan dan berita dengan kredibilitas yang dapat dipertanggungjawabkan.

\section{HASIL DAN PEMBAHASAN}

\section{Dampak Pandemi COVID-19 Terhadap Industri Perfilman Korea Selatan}

Pandemi COVID-19 pertama kali teridentifikasi di Korea Selatan pada 20 Januari 2020 dan merupakan negara pertama di luar Cina yang terkonfirmasi terdampak pandemi COVID-19. Sama seperti negara-negara lainnya yang terdampak pandemi COVID-19, jumlah pasien terkonfirmasi positif COVID-19 terus meningkat pada bulan Maret dan mengalami kenaikan signifikan pada bulan Agustus dengan persebaran ke banyak kota di Korea Selatan. Pemerintah Korea Selatan menerapkan kebijakan pembatasan kontak sosial yang sangat ketat pada masyarakatnya untuk memperlambat penyebaran virus COVID-19 agar tidak meluas.

Tidak hanya mengancam keamanan dan kesehatan negara, pandemi COVID-19 juga memberikan dampak pada sektor-sektor lainnya terutama pada sektor sosial, ekonomi, hingga politik negara (Klingebiel, 2020). Berdasarkan laporan Kementerian Budaya, Olahraga, dan Pariwisata Korea Selatan (MCST) tahun 2020 industri budaya Korea Selatan mengalami penurunan sebesar 38,8\% hanya dalam kurun waktu awal semester tahun 2020. Industri perfilman mengalami penurunan pendapatan yang cukup signifikan sejak munculnya pandemi COVID-19 akibat penutupan sebagian besar rantai 
bioskop global sehingga memberikan dampak pada penurunan penjualan tiket bioskop untuk produk film Korea Selatan di pasar ekspor bioskop global.

Kebijakan pembatasan kontak sosial oleh pemerintah Korea Selatan dan juga penutupan rantai bioskop hampir di seluruh negara di dunia memberikan dampak besar bagi industri perfilman Korea Selatan. Proses produksi mengalami penundaan dan bahkan dihentikan. Distribusi film melalui pasar bioskop yang merupakan sumber pendapatan utama produser film terhenti. Penjualan tiket bioskop pada tahun 2020 mencetak rekor penjualan terendah dalam 16 tahun sejarah industri perfilman Korea Selatan dengan jumlah penjualan sebanyak 59,52 juta tiket. Angka ini bahkan lebih rendah dari total penjualan tahun 2004 sebesar 69,25 juta tiket yang merupakan tahun pertama perfilman Korea Selatan menjadi sektor industri setelah pemerintahnya serius memperhatikan industri perfilmannya.

Penurunan yang cukup drastis tersebut menyebabkan beberapa perusahaan bioskop memutuskan untuk menutup beberapa bioskopnya. Bahkan, CGV yang merupakan perusahaan layanan jasa bioskop terbesar di Korea Selatan dan menduduki peringkat kelima di dunia memutuskan untuk menutup permanen 35 dari 116 bioskop yang tersebar di Korea Selatan. CGV juga menutup 30\% dari total jumlah layar di seluruh cabang CGV global. Hal tersebut disebabkan oleh turunnya jumlah pengunjung bioskop yang merupakan dampak dari kebijakan pembatasan kontak sosial oleh pemerintah dan perubahan budaya konsumsi film masyarakat seperti yang telah dijelaskan di atas (Kan, 2020).

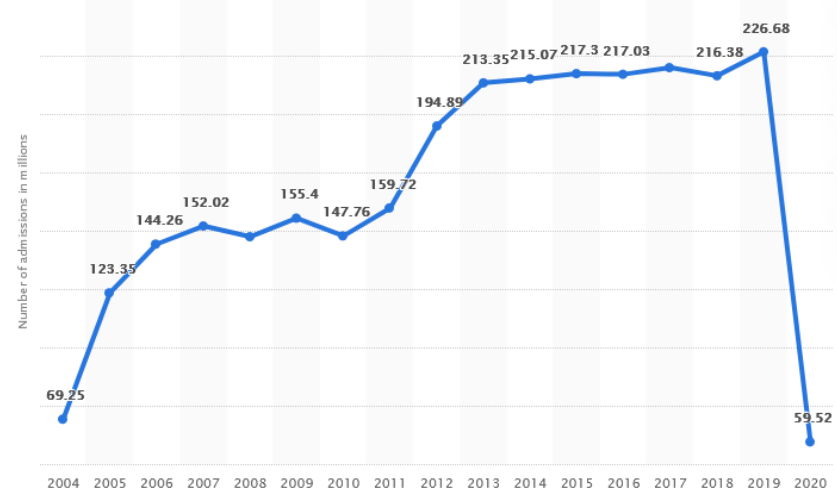

Grafik 2. Data Jumlah Total Penjualan Tiket Bioskop Korea Selatan tahun 2004-2020 (dalam satuan juta)

Sumber: (Waldeck, 2021)

Turunnya penjualan tiket bioskop produk film Korea Selatan secara langsung juga mempengaruhi data pendapatan industri perfilman karena hampir setengah dari pendapatan film bergantung pada penjualan tiket bioskop. Tercatat dalam buku laporan tahunan KOFIC tahun 2021, pendapatan industri perfilman melalui pasar bioskop tahun 2020 mengalami penurunan sebesar 73,3\% dari tahun sebelumnya dengan jumlah total pendapatan sebesar 510,4 miliar won, selaras dengan penurunan penjualan tiket bioskop film produksi Korea Selatan pada tahun 2020. KOFIC sendiri menjelaskan bahwa penurunan performa industri perfilman Korea Selatan merupakan suatu hal yang tidak dapat dicegah karena pada dasarnya penurunan tersebut juga terjadi di seluruh negara akibat kondisi pandemi COVID-19 yang mau tidak mau menghambat dan menghentikan rantai penjualan film melalui pasar bioskop. Pasar industri perfilman Korea Selatan yang diakui dan dilaporkan secara legal terdiri dari pasar bioskop, TV VOD atau TV kabel; langganan, Internet VOD atau OTT; layanan streaming, DVD, dan distribusi melalui saluran televisi. 


\section{Popularitas Netflix dan Perubahan Budaya Konsumsi Film}

Teknologi media film mengalami perkembangan yang cukup signifikan dimulai dari penggunaan proyektor film yang juga terus berubah seiring dengan berjalannya waktu, hingga pada masa sekarang di mana film dapat dinikmati hanya dengan melalui gawai. Budaya menonton film sangat lekat dengan bioskop atau teater yang umumya menayangkan film di studio besar dengan menggunakan sistem tiket sesuai dengan jadwal tayang film tertentu. Seiring dengan arus globalisasi, industri perfilman juga ikut mengalami perubahan, baik dari kualitas produksi, media distribusi, hingga target pasarnya. Sebelum tahun 1980an, film selalu di distribusikan melalui bioskop untuk memberikan pengalaman menonton film dengan layar yang besar dan kualitas suara yang baik serta ditujukan untuk ditonton oleh penonton dengan jumlah besar (pasangan, keluarga, dan kelompok pertemanan), sehingga budaya menonton film di bioskop sangat lekat dengan kegiatan bersosialisasi antar manusia (Smith, 2010). Hingga kemudian pada awal tahun 2000an seiring dengan makin maraknya pengguna internet dan kebutuhan konsumen film dengan produk yang praktis atau mudah diakses, teknologi distribusi film kembali mengalami perkembangan dengan munculnya teknologi Over The Top (OTT). OTT lebih lekat dengan istilah layanan streaming dengan memberikan layanan akses film melalui aplikasi yang dapat diakses di gawai apapun yang dapat tersambung pada internet publik (Halton, 2021).

Dengan munculnya teknologi OTT dan didukung dengan kondisi pandemi COVID19 yang tidak memungkinkan masyarakat untuk mengakses bioskop, secara tidak langsung menimbulkan perubahan budaya konsumsi masyarakat terhadap film. Perubahan budaya konsumsi masyarakat dalam mengakses film melalui platform layanan streaming tersebut pada awalnya sudah muncul jauh sebelum terjadinya pandemi COVID19, seiring dengan munculnya layanan streaming di pasar kedua (release windows) distribusi film (Mikos, 2020). Hanya saja, pandemi COVID-19 mempercepat dan memperluas perubahan budaya konsumsi masyarakat terhadap film akibat sempitnya peluang untuk mengakses film (lihat grafik 3).

Aliloupour (2016) menjelaskan bahwa perubahan budaya konsumsi tersebut didorong oleh banyak dan luasnya jangkauan konten film yang ditawarkan oleh layanan streaming dibandingkan dengan yang ditawarkan oleh bioskop, serta perbandingan harga untuk mengakses film tertentu dari kedua pasar film tersebut. Hal tersebut didukung dengan banyaknya konten film yang ditawarkan oleh Netflix baik dari segi negara asal produksi film (bahasa yang digunakan) dan jangkauan tahun rilis film yang sangat sulit ditemukan di pasar bioskop karena pada umumnya bioskop hanya menawarkan film-film yang dirilis pada periode tersebut dengan masa penayangan yang terbatas.

Selain itu, dari segi harga layanan streaming terhitung jauh lebih terjangkau dibandingkan dengan bioskop. Misalnya, peneliti membandingkan harga berlangganan Netflix Korea Selatan dengan jangkauan harga sekitar 9.500-14.500 won per bulannya, sedangkan untuk jangkauan harga tiket film bioskop CGV di Korea Selatan sekitar 6.00035.000 won per satu tiket filmnya (Netflix, Plan Selection, 2021 ; CGV, 2021). Keefektifan dan efisiensi dalam akses film yang ditawarkan oleh layanan streaming tersebut mendorong banyak konsumen film beralih dari mengakses film melalui bioskop menjadi menggunakan layanan streaming. 


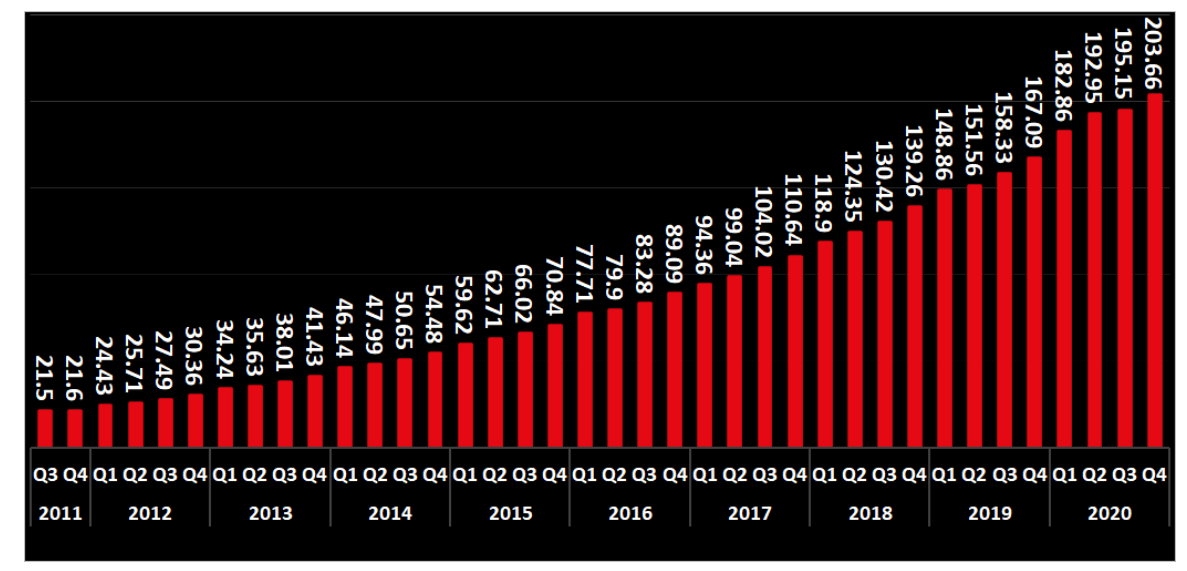

Grafik 3. Data Pertumbuhan Jumlah Pelanggan Layanan Streaming Netflix Global Tahun 2011-2020 Sumber: (Iqbal, 2021)

Pasar konten video digital global memiliki persaingan yang cukup ramai dengan banyaknya pilihan platform layanan streaming film seperti Netflix, Disney+, Hulu, Amazon Prime, HBO Max, dan iQIYI. Namun, Netflix memiliki pangsa pasar yang lebih besar dibandingkan dengan platform layanan streaming lainnya (lihat gambar 3). Tercatat pada awal bulan Januari tahun 2021, Netflix memiliki lebih dari 203,66 juta pelanggan berbayar dari 190 negara dengan pendapatan mencapai 6,6 milyar dollar AS yang menjadikan Netflix sebagai platform layanan streaming nomor satu dalam pasar konten video digital global (Iqbal, 2021). Netflix sendiri merupakan perusahan yang mengalami transisi bisnis dari perusahaan distributor DVD menjadi perusahaan penyedia layanan jasa streaming pada tahun 2007 sebagai distributor film secara digital dengan pembelian hak cipta dari distributor utama rumah produksi film. Hingga pada tahun 2013 Netflix memperluas jangkauan bisnisnya tidak hanya sebagai distributor tetapi juga menjadi produsen film dengan kegiatan produksi di bawah Netflix Original (Fernandez, 2021).

Netflix pertama kali memasuki pasar industri hiburan Korea Selatan pada tahun 2016 sebagai distributor dan produsen untuk film dan serial drama ke pasar digital global. Sejak masuknya Netflix pada tahun 2016 hingga akhir tahun 2020, Netflix telah menghabiskan dana sekitar 700 juta dollar AS untuk membeli hak cipta tayang, pembangunan fasilitas untuk pelaksanaan kegiatan produksi film dan seri drama Korea Selatan (Brzeski, Netflix Expands South Korean Footprint, Leasing Two Production Facilities, 2021). Hal tersebut disebabkan oleh tingginya minat pengguna Netflix global pada konten Korea Selatan sehingga mendorong tingginya jumlah konten Korea Selatan yang terdapat dalam katalog Netflix. Menurut Surfshark (2021), Netflix memuat 188 konten produksi Korea Selatan dalam bentuk film, drama, hingga variety shows, dengan jumlah film yang didistribusikan melalui Netflix lebih dari 75 judul film. Netflix menjadi fasilitator pasar bebas film bagi Korea Selatan akibat samarnya batasan negara dalam platform tersebut sehingga mempermudah konten film Korea Selatan untuk dapat dikonsumsi oleh masyarakat global tanpa harus melakukan jual-beli hak cipta film pada tiap rantai bioskop tiap negara tujuan ekspor. 


\section{Total Jumlah Pelanggan Berbayar Layanan Streaming Global}

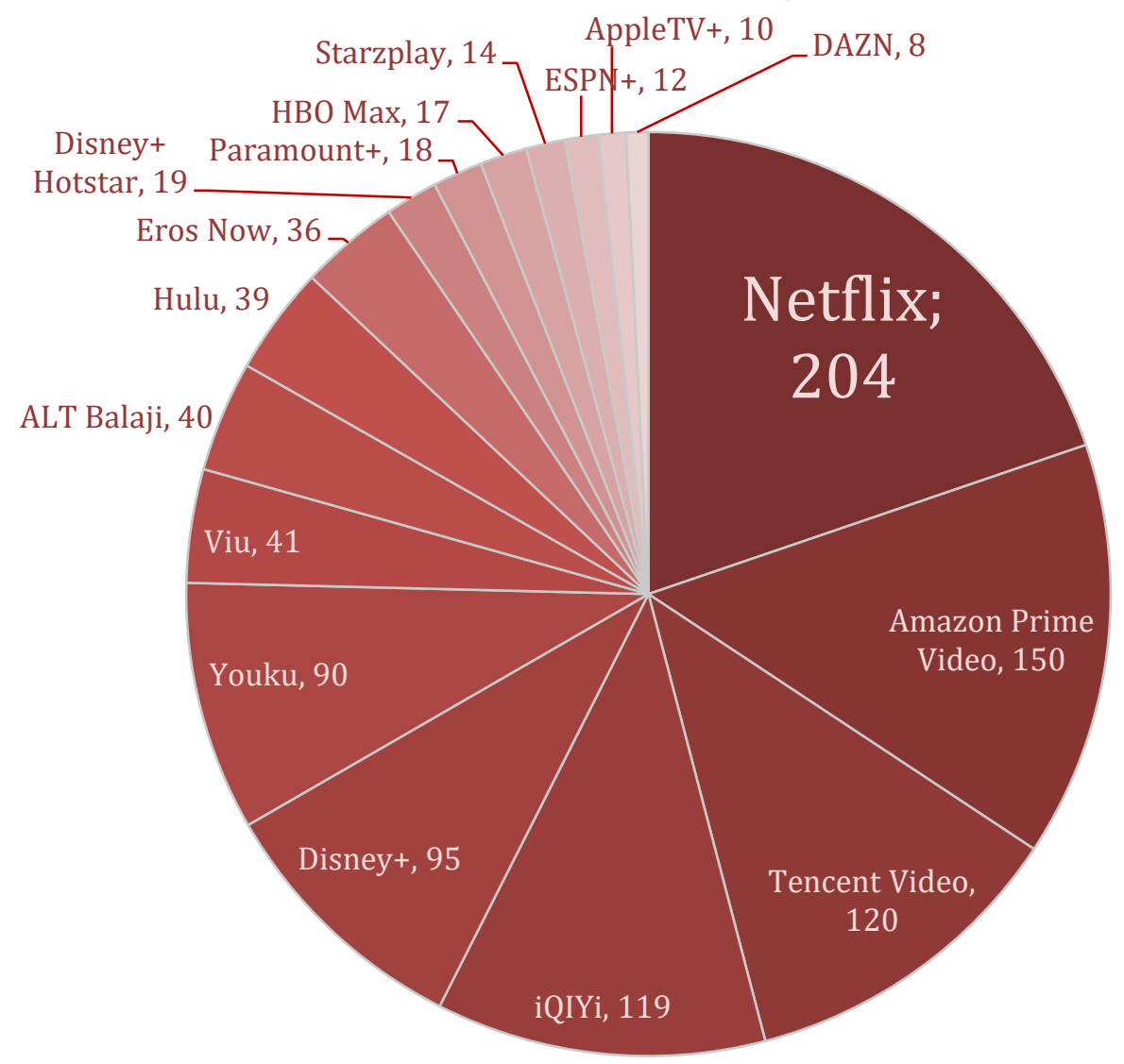

Grafik 4. Pangsa Pasar Platform Layanan Streaming Global (berdasarkan total jumlah pelanggan berbayar; dalam satuan juta) Sumber: (Wallach, 2021)

\section{Transformasi Pemasaran Film Korea Selatan: Pasar Film Bioskop Menjadi Pasar Film Digital}

Dengan kondisi pasar bioskop global yang tidak memungkinkan proses distribusi film, baik diakibatkan oleh turunnya minat konsumen maupun kebijakan masing-masing pemerintah negara terkait pembatasan kontak sosial, media streaming menjadi pasar alternatif untuk mengekspor film. Hal tersebut diakibatkan oleh luasnya jangkauan pasar platform layanan streaming, terutama Netflix yang mencapai 190 negara di dunia sehingga dapat dikatakan bahwa Netflix memudahkan akses dan meningkatkan pasar film global.

Industri perfilman Korea Selatan menggunakan platform layanan streaming Netflix untuk mencapai keuntungan penjualan ekspor film melalui penjualan hak cipta tayang, dan penjualan film di bawah produksi dan distribusi Netflix Original. Bahkan, dapat dikatakan bahwa industri perfilman Korea Selatan mulai menunjukkan kenaikan distribusi pada pasar ekspor melalui platform layanan streaming akibat kondisi pasar domestik bioskop yang tidak dapat memberikan jumlah keuntungan yang besar di tengah kondisi pandemi COVID-19 (KOFIC K. F., 2021).

Berikut merupakan data cara akses konsumen global di luar Korea Selatan terhadap konten budaya film yang menunjukkan tingginya penggunaan platform layanan streaming dengan persentase 72,5\% oleh konsumen film global pada tahun 2020, 
dibandingkan dengan akses melalui bioskop yang hanya mencapai 23,9\%. Hal tersebut juga dipertegas dengan naiknya persentase saluran akses melalui layanan streaming dari $67,5 \%$ pada tahun 2019 , menjadi $72,5 \%$ pada tahun 2020 dengan kenaikan sebesar $5 \%$.

Tabel 2. Saluran Akses Masyarakat Global Terhadap Konten Budaya Film Korea Selatan Tahun 2016-2020

\begin{tabular}{|c|c|c|c|c|c|c|}
$\begin{array}{c}\text { Konten } \\
\text { Budaya }\end{array}$ & $\begin{array}{c}\text { Saluran } \\
\text { Akses }\end{array}$ & 2016 & 2017 & 2018 & 2019 & 2020 \\
\hline \multirow{4}{*}{ FILM } & $\begin{array}{c}\text { Online/Mobile } \\
\text { Platform } \\
\text { (OTT) }\end{array}$ & $45 \%$ & $56,8 \%$ & $69,8 \%$ & $67,5 \%$ & $72,5 \%$ \\
\cline { 2 - 7 } & TV & $54,5 \%$ & $60,6 \%$ & $54,7 \%$ & $58,3 \%$ & $61,5 \%$ \\
\cline { 2 - 7 } & Offline & - & - & $24,4 \%$ & $24,9 \%$ & $27,6 \%$ \\
\cline { 2 - 7 } & $\begin{array}{c}\text { Cabang } \\
\text { Bioskop }\end{array}$ & - & - & - & $25,7 \%$ & $23,9 \%$ \\
\hline
\end{tabular}

Sumber: (KOFICE, 2021)

Netflix yang telah memasuki industri media dan entertainment Korea Selatan sejak tahun 2016 pertama kali memulai kerja sama distribusi produk film pada tahun 2017 dengan membeli hak cipta tayang film Pandora (판도라). Film ini berada di bawah rumah produksi dan distribusi Next Entertainment World (NEW) yang sebelumnya telah dipasarkan melalui bioskop pada tahun 2016 (Park, 2016). Hingga tahun 2019, industri perfilman Korea Selatan masih mengutamakan ekspor film melalui rantai bioskop internasional sehingga dalam katalog Netflix jumlah film Korea Selatan masih minim.

Kemudian, dengan kondisi pasar bioskop global yang terpuruk akibat pandemi COVID-19, distributor film Korea Selatan Little Big Picture menandatangani kontrak untuk distribusi film Time To Hunt yang diproduksi oleh Sidus Picture (Noh, 2020). Penandatanganan kontrak distribusi film Time To Hunt oleh Netflix tersebut menjadi titik awal munculnya transformasi pemasaran ekspor film Korea Selatan yang menggunakan platform layanan streaming sebagai screen pertama dari perilisan film. Hal tersebut didukung dengan popularitas platform layanan streaming Netflix dan kondisi pandemi COVID-19 sehingga sebagian kegiatan distribusi ekspor film Korea Selatan beralih menggunakan pemasaran digital.

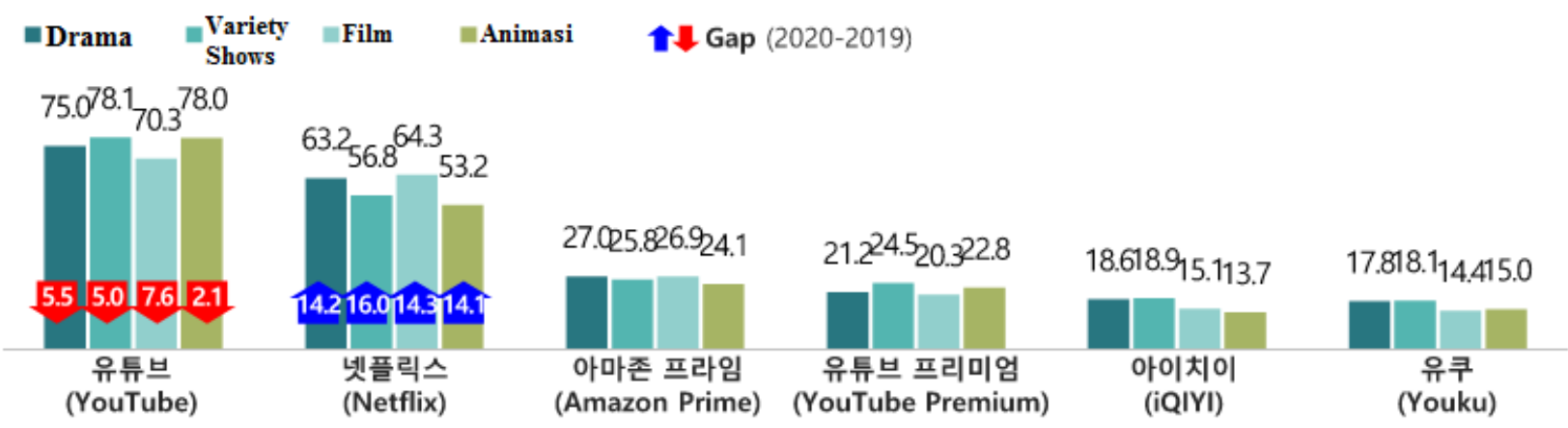

Grafik 5. Platform Layanan Streaming Online yang Digunakan Masyarakat Global Untuk Mengakses Konten Budaya Korea Selatan: Format Video Tahun 2020

Sumber: (KOFICE, 2021)

Merespon penurunan performa industri perfilman Korea Selatan yang juga mengakibatkan turunnya pendapatan penjualan film, beberapa rumah produksi film yang telah memiliki jadwal rilis film pada tahun 2020 mengubah haluan distribusi pasarnya dengan memanfaatkan pasar film digital melalui layanan streaming. Bahkan beberapa film yang dirilis pada tahun 2020 tidak menggunakan pasar film bioskop dan hanya fokus pada distribusi melalui layanan streaming. Dengan kata lain, film tersebut tidak memiliki 
pendapatan dari pasar bioskop melainkan hanya secara eksklusif dari profit penjualan film keseluruhan dari layanan streaming. Seperti film Time to Hunt yang telah disebutkan di atas mengubah haluan pasar distribusinya secara keseluruhan dari pasar bioskop menjadi melalui layanan streaming Netflix. Selain itu juga terdapat film Parasite ( $>1$ 생충; gisaengchung), Train to Busan (부산행; busanhaeng), Peninsula (반도; bando), \#Alive (\#살아 있다; sara itta), Time to Hunt (사냥의 시간, sanyangeu sigan) dan Extreme Job (극한 직업; geughan jigeop) yang menjadi poros utama popularitas film Korea Selatan di pasar film global di tahun 2020 (KOFICE, 2021).

Dari keenam film yang telah disebutkan di atas, empat di antaranya telah mencapai kesepakatan pembelian hak cipta tayang oleh Netflix dengan Content Panda sebagai distributor internasional dari Next Entertainment World (NEW) untuk film Train to Busan dan Pandora, serta pembelian hak cipta tayang dari CJ Entertainment untuk film Parasite dan Extreme job. Begitu juga dengan \#Alive dan Time to Hunt yang sejak awal rilis telah menjadi bagian produksi dan distribusi utama Netflix (Netflix, Entertainment, 2017). Perubahan cara distribusi pemasaran film tersebut diakibatkan karena kondisi pasar bioskop baik dalam Korea Selatan dan internasional yang tidak stabil serta kemungkinan tidak tercapainya break-even point (BEP) dari keuntungan penjualan tiket bioskop dengan biaya produksi sehingga OTT menjadi pilihan paling logis bagi distributor film yang mengalami penundaan akibat pandemi COVID-19. Time to Hunt menjadi film produksi Korea Selatan pertama yang menggunakan distributor layanan streaming Netflix Original yang kemudian diikuti oleh film Call, What Happened to Mr. Cha? dan Space Sweepers. Dengan digunakannya layanan streaming Netflix, film-film tersebut tidak memiliki batasan pasar domestik ataupun internasional karena proses rilis yang dilaksanakan serentak di 190 negara yang memiliki izin layanan streaming Netflix sehingga pendapatan film tersebut terakumulasi dari penjualan keseluruhan secara global.
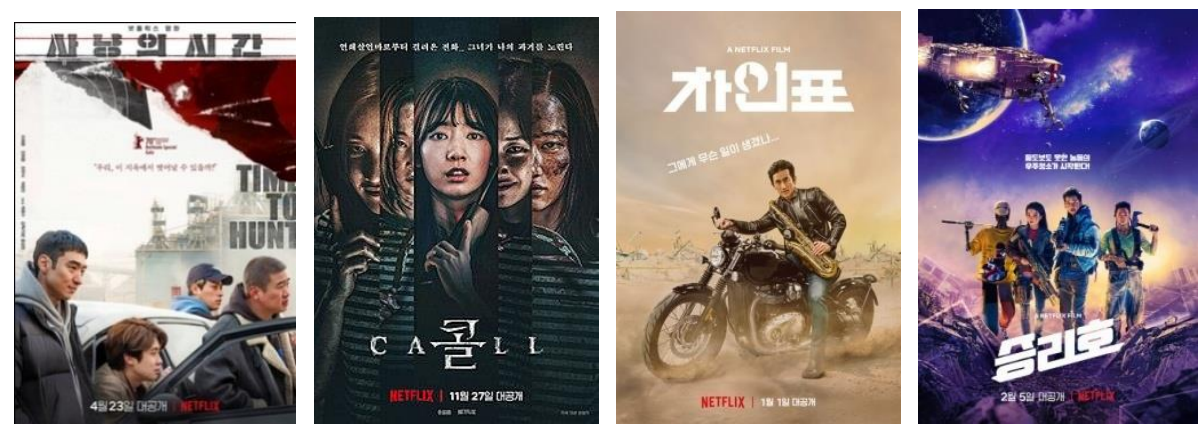

Gambar 1. Poster film Time to Hunt, Call, What Happened to Mr. Cha? dan Space Sweepers Sumber: Netflix Korea

\section{Dampak Transformasi Pemasaran Ekspor Film Korea Selatan}

Transformasi pemasaran ekspor film dengan menggunakan Netflix sebagai alternatif pemasaran film di pasar global memberikan dampak kenaikan pada sektor ekspor industri perfilman Korea Selatan pada tahun 2020. Pasar ekspor industri perfilman Korea Selatan dengan tujuan pasar global secara keseluruhan menunjukkan statistik data yang positif. Kenaikan penjualan sebesar 13,3\% dibandingkan dengan tahun 2019 dengan total jumlah penjualan sebesar 83.605.054 dollar AS. Total penjualan hanya pada produk film menjadi sebesar 54.156.980 dollar AS, meningkat 43\% dari tahun 2019 . Kenaikan ekspor film tersebut sebagian besar berasal dari penjualan film melalui media OTT, bukan melalui pasar tradisional bioskop. Hal ini diakibatkan lumpuhnya pasar bioskop global dan beralih pada pasar digital film melalui layanan streaming (lihat Grafik 4) (KOFIC K. F., 2021). 
Tabel 3. Data Total Pasar Ekspor Industri Perfilman Korea Selatan Tahun 2016-2020 (dalam satuan dollar AS)

\begin{tabular}{|c|c|c|c|c|c|c|}
\hline & & 2016 & 2017 & 2018 & 2019 & 2020 \\
\hline \multirow{3}{*}{$\begin{array}{l}\text { Ekspo } \\
\text { r Film }\end{array}$} & $\begin{array}{c}\text { Jumlah } \\
\text { pendapatan } \\
\text { penjualan hak } \\
\text { cipta }\end{array}$ & 30.106 .468 & 34.771 .671 & 37.436 .403 & 36.276 .567 & 51.290 .400 \\
\hline & $\begin{array}{c}\text { Pendapatan } \\
\text { tambahan tidak } \\
\text { langsung ekspor }\end{array}$ & 13.787 .069 & 5.954 .486 & 4.170 .844 & 1.600 .749 & 2.866 .580 \\
\hline & Sub total & 43.893 .537 & 40.726 .157 & 41.607 .247 & 37.877 .316 & 54.156 .980 \\
\hline \multirow{3}{*}{$\begin{array}{c}\text { Ekspo } \\
\text { r Jasa } \\
\text { Indust } \\
\text { ri } \\
\text { Perfil } \\
\text { man }\end{array}$} & $\begin{array}{c}\text { Ekspor jasa } \\
\text { teknologi }\end{array}$ & 38.613 .215 & 70.184 .428 & 35.361 .845 & 19.089 .682 & 9.761 .760 \\
\hline & $\begin{array}{c}\text { Pendapatan tidak } \\
\text { langsung dari } \\
\text { daya tarik lokasi }\end{array}$ & 18.582 .623 & 7.878 .294 & 3.395 .117 & 16.815 .191 & 19.686 .314 \\
\hline & Sub total & 57.195 .838 & 78.062 .722 & 38.756 .962 & 35.904 .873 & 29.448 .074 \\
\hline \multicolumn{2}{|c|}{ Jumlah total } & $\begin{array}{c}101.089 .3 \\
75\end{array}$ & $\begin{array}{c}118.788 .8 \\
79\end{array}$ & $\begin{array}{c}80.364 .20 \\
9\end{array}$ & $\begin{array}{c}73.782 .18 \\
9\end{array}$ & $\begin{array}{c}83.605 .05 \\
4\end{array}$ \\
\hline \multicolumn{2}{|c|}{ \% perbandingan } & $82,1 \%$ & $17,5 \%$ & $-32,3 \%$ & $-8,2 \%$ & $13.3 \%$ \\
\hline
\end{tabular}

Sumber: (KOFIC K. F., 2021)

Dengan kenaikan penjualan ekspor film yang mencapai 54 juta dollar AS tersebut memberikan sedikit harapan pada industri perfilman Korea Selatan karena tidak sepenuhnya mengalami penurunan akibat pandemi COVID-19. Penjualan ekspor produk film tersebut terbagi atas penjualan hak cipta keseluruhan (all rights) film, hak cipta penayangan bioskop, hak cipta tambahan (penjualan film melalui media digital), dan hak cipta untuk remake film. Untuk penjualan film melalui layanan streaming sendiri masuk ke dalam kategori penjualan hak cipta tambahan yang pada tahun 2020 telah menyumbangkan penjualan sebesar 13,8\% dari total penjualan dengan jumlah 7.095.358 dollar AS. Angka ini 13,5\% lebih besar dibandingkan penjualan hak cipta penayangan bioskop yang hanya sebesar 130.600 dollar AS atau setara 0,3\% dari total penjualan ekspor film tahun 2020 (KOFIC K. F., 2021).

Menurut Minyoung Kim, Vice President Netflix untuk konten Korea Selatan dalam (Brzeski, 2021), konsumen Netflix di seluruh dunia sedang berada di puncak minatnya terhadap budaya, aktor, dan juga alur cerita yang ditawarkan oleh film produksi Korea Selatan. Hal tersebut juga dibuktikan dengan hasil penelitian KOFICE tentang popularitas film dalam platform layanan streaming Netflix di kalangan konsumen film global (lihat gambar 2). Data tersebut menunjukkan bahwa pengguna Netflix di benua Amerika dan Eropa menduduki peringkat tertinggi dalam kegiatan konsumsi film melalui Netflix.

Respon positif film Korea Selatan di pasar film internasional pada tahun 2020 yang memberikan keuntungan bagi industri perfilman Korea Selatan disebabkan oleh kepopuleran budaya Korea atau Hallyu dan kesuksesan fenomenal film Parasite sehingga memberikan citra positif film produksi Korea Selatan di mata konsumen film internasional (Choudhury, 2021). Kepopuleran hallyu di kalangan masyarakat internasional juga memberikan dampak positif bagi pasar digital layanan streaming yang menyediakan konten-konten budaya Korea Selatan, termasuk layanan streaming Netflix. Besarnya pasar konten Korea Selatan berbasis video (film, TV series, dan variety shows) mendorong Netflix untuk berinvestasi dengan jumlah yang besar sebagai bentuk partisipasi promosi atau penyebaran budaya Korea Selatan agar dapat diakses dengan mudah oleh konsumen internasional. 
Tabel 4. Data Ekspor Film Korea Selatan Berdasarkan Jenis Hak Cipta Tahun 2016-2020

\begin{tabular}{|c|c|c|c|c|c|c|c|c|c|c|}
\hline \multirow{2}{*}{ Jenis } & \multicolumn{2}{|c|}{2016} & \multicolumn{2}{|c|}{2017} & \multicolumn{2}{|c|}{2018} & \multicolumn{2}{|c|}{2019} & \multicolumn{2}{|c|}{2020} \\
\hline & $\begin{array}{l}\text { Nilai } \\
\text { Harga }\end{array}$ & $\%$ & $\begin{array}{l}\text { Nilai } \\
\text { Harga }\end{array}$ & $\%$ & $\begin{array}{l}\text { Nilai } \\
\text { Harga }\end{array}$ & $\%$ & $\begin{array}{l}\text { Nilai } \\
\text { Harga }\end{array}$ & $\%$ & $\begin{array}{l}\text { Nilai } \\
\text { Harga }\end{array}$ & $\%$ \\
\hline All Rights & $\begin{array}{c}16.842 . \\
920\end{array}$ & $\begin{array}{l}55, \\
9 \%\end{array}$ & $\begin{array}{c}24.710 . \\
624\end{array}$ & $\begin{array}{l}71, \\
1 \%\end{array}$ & $\begin{array}{c}24.992 . \\
002\end{array}$ & $\begin{array}{l}66, \\
8 \%\end{array}$ & $\begin{array}{c}28.003 . \\
695\end{array}$ & $\begin{array}{l}77, \\
2 \%\end{array}$ & $\begin{array}{c}43.067 \\
316\end{array}$ & $\begin{array}{l}84, \\
0 \%\end{array}$ \\
\hline $\begin{array}{c}\text { Hak } \\
\text { Cipta } \\
\text { Bioskop }\end{array}$ & $\begin{array}{c}410.78 \\
9\end{array}$ & $\begin{array}{c}1,4 \\
\%\end{array}$ & $\begin{array}{c}104.07 \\
0\end{array}$ & $\begin{array}{c}0,3 \\
\%\end{array}$ & $\begin{array}{c}1.422 .9 \\
00\end{array}$ & $\begin{array}{c}3,8 \\
\%\end{array}$ & $\begin{array}{c}271.00 \\
0\end{array}$ & $\begin{array}{c}0,7 \\
\%\end{array}$ & $\begin{array}{c}130.60 \\
0\end{array}$ & $\begin{array}{c}0,3 \\
\%\end{array}$ \\
\hline $\begin{array}{c}\text { Hak } \\
\text { Cipta } \\
\text { Tambahan } \\
*\end{array}$ & $\begin{array}{c}11.742 . \\
759\end{array}$ & $\begin{array}{l}39, \\
0 \%\end{array}$ & $\begin{array}{c}8.325 .0 \\
77\end{array}$ & $\begin{array}{l}23, \\
9 \%\end{array}$ & $\begin{array}{c}10.611 . \\
481\end{array}$ & $\begin{array}{l}28, \\
3 \%\end{array}$ & $\begin{array}{c}6.962 .8 \\
72\end{array}$ & $\begin{array}{l}19, \\
2 \%\end{array}$ & $\begin{array}{c}7.095 .3 \\
58\end{array}$ & $\begin{array}{l}13, \\
8 \%\end{array}$ \\
\hline $\begin{array}{c}\text { Hak } \\
\text { Cipta } \\
\text { Remake }\end{array}$ & $\begin{array}{c}1.110 .0 \\
00\end{array}$ & $\begin{array}{c}3,7 \\
\%\end{array}$ & $\begin{array}{c}1.631 .9 \\
00\end{array}$ & $\begin{array}{l}4,7 \\
\%\end{array}$ & $\begin{array}{c}410.00 \\
0\end{array}$ & $\begin{array}{l}1,1 \\
\%\end{array}$ & $\begin{array}{c}1.038 .0 \\
00\end{array}$ & $\begin{array}{c}2,9 \\
\%\end{array}$ & $\begin{array}{c}997.12 \\
6\end{array}$ & $\begin{array}{l}1,9 \\
\%\end{array}$ \\
\hline TOTAL & $\begin{array}{c}30.106 \\
.468\end{array}$ & $\begin{array}{c}100 \\
\%\end{array}$ & $\begin{array}{c}34.771 \\
.671\end{array}$ & $\begin{array}{c}100 \\
\%\end{array}$ & $\begin{array}{c}37.436 \\
.403\end{array}$ & $\begin{array}{c}100 \\
\%\end{array}$ & $\begin{array}{c}36.276 \\
.567\end{array}$ & $\begin{array}{c}100 \\
\%\end{array}$ & $\begin{array}{c}51.290 \\
.400\end{array}$ & $\begin{array}{c}100 \\
\%\end{array}$ \\
\hline
\end{tabular}

Sumber: (KOFIC K. F., 2021)

\begin{tabular}{|c|c|c|c|c|c|c|c|c|c|c|c|}
\hline $\begin{array}{c}\text { Konten } \\
\text { per benua }\end{array}$ & \begin{tabular}{|l|} 
Jumlah \\
responden
\end{tabular} & $\begin{array}{c}\text { 유튜브 } \\
\text { (YouTube) }\end{array}$ & $\begin{array}{l}\text { 넷풀릭스 } \\
\text { (Netflix) }\end{array}$ & $\begin{array}{c}\text { 아마존 } \\
\text { 프라임 } \\
\text { (Amazon } \\
\text { Prime) }\end{array}$ & $\begin{array}{c}\text { 유튜브 } \\
\text { 프리미엄 } \\
\text { (YouTube } \\
\text { Premium) }\end{array}$ & $\begin{array}{c}\text { 아이치이 } \\
\text { (iQIYI) }\end{array}$ & $\begin{array}{c}\text { 유쿠 } \\
\text { (Youku) }\end{array}$ & 뷰(Viu) & $\begin{array}{l}\text { 아이 } \\
\text { 퓰릭스 } \\
\text { (ifflix) }\end{array}$ & $\begin{array}{c}\text { 훌루 } \\
\text { (Hulu) }\end{array}$ & $\begin{array}{l}\text { 슬링티비 } \\
\text { (SlingTV) }\end{array}$ \\
\hline 드라마 & $(3,186)$ & 75.0 & 63.2 & 27.0 & 21.2 & 18.6 & 17.8 & 14.1 & 12.1 & 11.2 & 7.1 \\
\hline 아시아.오세아니아 & $(1,981)$ & 74.6 & 55.9 & 21.0 & 18.8 & 26.3 & 20.4 & 22.7 & 15.1 & 8.5 & 6.4 \\
\hline 미주 & (402) & 71.1 & 85.1 & 47.3 & 24.1 & 7.0 & 13.4 & - & 6.5 & 19.9 & 8.2 \\
\hline 유럽 & (515) & 75.7 & 68.9 & 33.4 & 23.7 & 3.9 & 11.3 & - & 4.7 & 120 & 6.8 \\
\hline 중동.아프리카 & (288) & 81.9 & 72.9 & 28.8 & 29.5 & 8.0 & 17.7 & - & 12.5 & 16.0 & 11.5 \\
\hline 예능 & $(2,813)$ & 78.1 & 56.8 & 25.8 & 24.5 & 18.9 & 18.1 & 13.2 & 12.5 & 11.8 & 8.1 \\
\hline 아시아.오세아니아 & $(1,741)$ & 78.5 & 50.8 & 19.6 & 21.1 & 24.8 & 19.8 & 21.3 & 14.9 & 8.9 & 7.2 \\
\hline 미주 & $(380)$ & 75.5 & 73.7 & 41.8 & 28.2 & 8.4 & 12.9 & - & 6.6 & 19.2 & 6.8 \\
\hline 유럽 & (437) & 77.3 & 59.0 & 34.1 & 31.1 & 9.6 & 15.8 & - & 6.4 & 14.2 & 9.4 \\
\hline 중동.아프리카 & (255) & 80.0 & 68.6 & 29.4 & 31.4 & 10.6 & 18.0 & - & 15.3 & 16.1 & 13.7 \\
\hline FILM & $(3,412)$ & 70.3 & 64.3 & 26.9 & 20.3 & 15.1 & 14.4 & 12.0 & 10.3 & 9.9 & 5.4 \\
\hline Asia; Oceania & $(1,923)$ & 71.1 & 55.9 & 20.7 & 19.1 & 23.6 & 19.1 & 21.3 & 14.2 & 7.9 & 6.1 \\
\hline Amerika & (577) & 65.2 & 83.9 & 43.0 & 20.8 & 3.6 & 73 & - & 3.3 & 15.4 & 4.5 \\
\hline Eropa & (583) & 66.7 & 67.1 & 29.7 & 19.6 & 3.1 & 7.0 & - & 3.1 & 6.9 & 2.9 \\
\hline Timur Tengah; Afrika & (329) & 80.9 & 74.2 & 30.4 & 27.1 & 6.7 & 12.8 & - & 12.5 & 17.3 & 7.3 \\
\hline 애니메이션 & $(2,931)$ & 78.0 & 53.2 & 24.1 & 22.8 & 13.7 & 15.0 & 7.7 & 9.0 & 10.5 & 6.1 \\
\hline 아시아-오세아니아 & $(1,507)$ & 78.5 & 47.0 & 21.1 & 220 & 21.9 & 20.2 & 15.0 & 13.3 & 9.1 & 7.6 \\
\hline 미주 & (577) & 78.7 & 64.1 & 32.8 & 220 & 4.5 & 8.7 & - & 3.3 & 14.9 & 4.2 \\
\hline 유럽 & (526) & 74.0 & 53.4 & 24.1 & 22.1 & 4.8 & 9.3 & - & 3.0 & 7.6 & 3.8 \\
\hline 중동.아프리카 & (321) & 81.3 & 62.3 & 22.1 & 28.7 & 6.2 & 11.5 & - & 9.0 & 14.0 & 6.5 \\
\hline
\end{tabular}

Gambar 2. Persentase Pengguna Platform Online Untuk Mengakses Konten Budaya Korea Selatan Per Regional: Konten Video Tahun 2020 (dalam satuan persen)

Sumber: (KOFICE, 2021) 
Kemudian, pada tahun 2020 di mana pasar layanan streaming mencapai puncak kepopulerannya, Netflix membangun fasilitas produksi film berupa studio setting produksi di Paju-si dan Yeoncheon-gun, Korea Selatan dengan luas mencapai $9000 \mathrm{~m}^{2}$. Studio ini ditujukan untuk memfasilitasi proses produksi film Korea Selatan yang berada di bawah rumah produksi Netflix Original (Netflix, 2021). Menurut Brzeski (2021), Netflix telah mengeluarkan budget sebesar 500 juta dollar AS untuk membeli hak cipta dan produksi konten Korea Selatan hanya dalam kurun waktu 2 bulan pertama tahun 2021. Dukungan langsung dari layanan streaming seperti Netflix tersebut memberikan kemudahan bagi film produksi Korea Selatan untuk dapat menambah jumlah film yang dapat dipasarkan di pasar film internasional sehingga juga dapat membantu memulihkan kondisi industri perfilman Korea Selatan.

\section{KESIMPULAN}

Perubahan alur pemasaran film global akibat pandemi COVID-19 dari pasar distribusi film melalui bioskop menjadi distribusi film melalui media digital atau layanan streaming merupakan bentuk respon pasar terhadap perubahan budaya konsumsi film masyarakat global (dalam hal ini adalah konsumen film) seiring dengan diberlakukannya kebijakan pemerintah negara di dunia terkait keamanan kesehatan yang tidak memungkinkan akses masyarakat terhadap bioskop. Hal tersebut sesuai dengan konsep transformasi pemasaran yang diusung oleh Kumar yang digunakan oleh penulis untuk menganalisis perubahan strategi pemasaran ekspor film Korea Selatan. Dalam penelitian ini dapat disimpulkan bahwa sebagian besar pelaku industri perfilman global mengubah pasar distribusi filmnya menggunakan platform layanan streaming sesuai dengan pertumbuhan pelanggan berbayar yang juga ikut mengalami peningkatan pada tahun 2020, serta pasar bioskop yang menunjukkan penurunan. Termasuk Korea Selatan yang merupakan negara dengan orientasi ekonomi ekspor juga menunjukkan perubahan cara distribusi ekspor produk budaya film dengan memanfaatkan platform layanan streaming Netflix yang memiliki pangsa pasar luas dibandingkan platform layanan streaming lainnya.

Dalam penelitian ini ditemukan bahwa dengan kegiatan ekspor produk film Korea Selatan yang memanfaatkan platform layanan streaming Netflix mempermudah perluasan pasar ekspor film Korea Selatan serta memotong atau menambah distribusi ekspor produk film yang sebelumnya melibatkan distributor film dari pihak Korea Selatan (sebagai eksportir) dengan distributor film negara-negara di luar Korea Selatan (sebagai importir) di saat menggunakan pasar bioskop. Hal ini memunculkan kenaikan pendapatan ekspor film produksi Korea Selatan sebesar 13,3\% pada tahun 2020 dengan jumlah film yang memasuki pasar ekspor sebanyak 975. Hal tersebut juga didukung dengan tingginya minat konsumen Netflix terhadap konten Korea Selatan terutama konten film, yang didukung dengan daya tarik konsumen global terhadap alur cerita, aktor, dan budaya Korea Selatan. Hal tersebut selaras dengan argumentasi peneliti terkait kenaikan persentase penjualan film produksi Korea Selatan di pasar film digital global, yang juga mengembalikan performa industri perfilman Korea Selatan di tengah keterpurukan pasar film domestik akibat penurunan penjualan melalui pasar bioskop.

Akibat kenaikan minat konsumen global terhadap film produksi Korea Selatan secara tidak langsung juga mendukung Netflix untuk terus mendukung kegiatan produksi film Korea Selatan melalui berbagai investasi baik sebagai penyedia fasilitas kegiatan produksi maupun sebagai produsen dan distributor utama film produksi Korea Selatan melalui Netflix Original. Dapat dilihat bahwa kerangka transformasi pemasaran yang diusung oleh Kumar dapat diterapkan untuk menganalisis perubahan strategi pemasaran ekspor produk film Korea Selatan yang terjadi akibat pandemi COVID-19, yang secara 
tidak langsung menyebabkan perubahan budaya menonton film masyarakat global dan didukung oleh popularitas teknologi media layanan streaming.

Peneliti berharap terdapat studi lanjutan dari penelitian ini terkait upaya pembenahan atau respon pemerintah Korea Selatan dari munculnya industri 4.0 di bidang industri film; terkait kebijakan pemerintah Korea Selatan mengenai kebijakan pembagian pangsa pasar tradisional dan digital film; dan juga terkait piracy atau pembajakan yang merupakan salah satu bentuk hambatan utama distribusi film melalui pasar digital yang juga merupakan bentuk kejahatan cyber.

\section{DAFTAR PUSTAKA}

Alexander, L. G. (2005). Case Studies and Theory Development in The Social Science. Cambridge: MIT Press.

Aliloupour, N. P. (2016). The Impact of Technology on the Entertainment Distribution Market: The Effects of Netflix and Hulu on Cable Revenue. Scripps Senior Theses , 130.

Brzeski, P. (2021, Januari 06). Netflix Expands South Korean Footprint, Leasing Two Production Facilities. Diakses di lama Hollywoodreporter: https://www.hollywoodreporter.com/news/netflix-expands-south-koreanfootprint-leasing-two-production-facilities pada 08 April 2021.

CGV. (2021). Ticket. Diakses di laman CGV Korea: http://www.cgv.co.kr/ticket/eng/newdefault.aspx pada 08 April 2021.

Choudhury, S. R. (2021, Februari 25). Netflix to spend $\$ 500$ million in South Korea this year to develop new content. Diakses di laman CNBC: https://www.cnbc.com/2021/02/25/netflix-nflx-to-spend-500-million-in-southkorea-in-2021.html pada 11 Maret 2021.

Fernandez, N. (2021, April 03). Streaming. Diakses di laman androidauthority: https://www.androidauthority.com/what-is-netflix-2-1136891/ pada 08 April 2021.

Halton, C. (2021, Januari 28). Over the Top (OTT). USA.

Ibbi, A. A. (2013). Hollywood, The American Image and The Global Film Industry. Cinej Cinema Journal , 93-106.

Iqbal, M. (2021, Maret 09). Netflix Revenue and Usage Statistics (2021). Diakses di laman Businessofapps: https://www.businessofapps.com/data/netflix-statistics/\#1 pada 08 April 2021.

Kan, H. W. (2020, Maret 29). S. Korean movie industry hit hard by COVID-19 outbreak. Nambusunhwan-ro, Seocho-gu, Seoul.

Kim, S. (2020). Netflix's Winning Strategies in South Korea and Changes in South Korean OTT Industry. 서울대학교 경영학 석사학위논문, 22-71.

Klingebiel, L. T. (2020). Republic of Korea and COVID-19: Gleaning governance lessons from a unique approach. UNDP: PATHFINDERS , 1-8.

KOFIC. (2019). Korean Cinema 2019. Busan: Korean Film Council.

KOFIC, K. F. (2021). 2020 년 한국 영화산업 결산. Busan: 영화진흥위원회.

KOFICE. (2021). 2021 해외 한류 실태 조사. Seoul: KOFICE.

Kumar, V. (2018). Transformative Marketing: The Next 20 Years. Journal of Marketing , 112.

Lulkowska, A. (2020, Januari 17). An Oscar for Parasite? The Global Rise of South Korean Film. Diakses di lama The Conversation. https://theconversation.com/an-oscarfor-parasite-the-global-rise-of-south-korean-film-128595 pada 21 Juni 2021.

MCST, R. o. (2020, Agustus 31). Korea's Nation Response to Covid-19 outbreak. Diakses di laman Korea.net: $\quad$ https://m.korea.net/english/Government/Current- 
Affairs/National-

Affairs $/$ view?affairId=2034\&subId=6\&articleId=56849\&contentGroupId=10852 $\underline{5}$ pada 07 Maret 2021.

Mikos, L. (2020). Film and Television Production and Consumption in Times of the COVID19 Pandemic - The Case of Germany. BALTIC SCREEN MEDIA REVIEW 2020 , 3034.

Mojo, B. O. (2020, Oktober 7). Parasite (2019). Diakses di laman box Office Mojo by IMDBpro: https://www.boxofficemojo.com/title/tt6751668/ pada 02 Oktober 2020.

Netflix. (2017, 15 November). Entertainment. Diakses dari laman Netflix: https://about.netflix.com/en/news/netflix-announces-psychokinesis-from-thedirector-of-train-to-busan pada 14 Mei 2021.

Netflix. (2021, Januari 06). Expanding Our Presence in Korea: Netflix Welcomes the New Year With Two New Production Facilities. Diakses di laman Netflix: https://about.netflix.com/en/news/expanding-our-presence-in-korea-netflixproduction-facilities pada 11 Maret 2021.

Netflix. (2021). Plan Selection. Diakses di laman Netflix: https://www.netflix.com/signup/planform pada 08 April 2021.

Noh, J. (2020, Maret 23). Contents Panda Considers Legal Action Over 'Time To Hunt' Netflix Deal. Diakses di laman Screendaily: https://www.screendaily.com/news/contents-panda-considers-legal-actionover-time-to-hunt-netflix-deal/5148399.article pada 14 April 2021.

Park, M. A. (2016, November 08). '판도라', 넷플릭스 손잡고 190여개국 서비스. Seoul, South Korea.

Richeri, G. (2016). Global film market, regional problems. Global Media and China , 312 330.

Ripley, N. (2021). Comscore Announces Global Box Office Totals For 2020. Comscore.

Ripley, N. (2020). Comscore Reports Highest Ever Worldwide Box Office. Comscore.

Smith, L. A. (2010, Februari 12). Studios Unlock DVD Release Dates: Movie Makers, Theater Owners Discuss Experimenting With Time Frames for Videos. USA.

Stoll, J. (2021, Januari 12). Media: TV, Video and Film. Diakses di laman Statista: https://www.statista.com/statistics/264429/global-box-office-revenue-byregion/ pada 28 Februari 2020.

Surfshark. (2021). Which Countries Get the Best-rated TV Shows \& Films on Netflix?. Diakses di laman Surfshark: https://surfshark.com/best-rated-netflix-shows-andmovies pada 08 April 2021.

Waldeck, Y. (2021, Februari 23). Media: TV, Video and Film. Diakses di laman Statista: https://www.statista.com/statistics/625814/south-korea-cinema-admissions/ pada 07 Maret 2021.

Wallach, O. (2021, Maret 31). Technology: Which Streaming Service Has the Most Subscriptions? Diakses di laman Visualcapitalist: https://www.visualcapitalist.com/which-streaming-service-has-the-mostsubscriptions/pada 08 April 2021. 